\title{
PROBLEMATIKA EVALUASI PEMBELAJARAN DALAM MENCAPAI TUJUAN PENDIDIKAN DI MASA PANDEMI COVID 19
}

\author{
SUWARDI \\ SMKN 1 Sekotong, Lombok Barat, NTB \\ E-mail : dhilaardhi@gmail.com
}

\begin{abstract}
ABSTRAK
Tulisan ini bertujuan untuk mengetahui apakah ada permasalahan dalam pelaksanaan evaluasi pembelajaran dalam rangka mencapai tujuan pendidikan selama pandemi Covid 19. Tulisan ini menggunakan metode penelitian kualitatif, yaitu studi literatur (Literature Study). Berdasarkan uraian di atas, selama pandemi Covid 19, pembelajaran daring merupakan hal mutlak yang harus dilakukan baik dalam proses kegiatan belajar mengajar maupun mengevaluasi pembelajaran. Semua ini dilakukan untuk mencapai tujuan, metode, materi, dan evaluasi pembelajaran yang efektif dan berkualitas. Kegiatan evaluasi inilah yang membuat guru bertindak sebagai perantara untuk mencapai tujuan pendidikan selama pandemi. Guru harus memahami tujuan dan fungsi evaluasi pembelajaran selama pandemi sehingga mampu menyiapkan metode strategis yang andal dalam pembelajaran daring sehingga dapat menciptakan pembelajaran yang nyaman, menyenangkan, dan menarik, sehingga kegiatan evaluasi berfungsi dengan baik. Pada kenyataannya, ada guru yang tidak peduli tentang hal ini. Dalam pembelajaran, yang terpenting adalah guru masuk ke dalam kelas, mengajar, melakukan evaluasi monoton, mengutamakan nilai akhir, melaksanakan waktu evaluasi sesuai dengan keinginan dan kenyamanan guru terlepas dari konsep dasar evaluasi untuk keperluan pendidikan. Asumsi terpenting guru di akhir semester adalah ia telah mencapai target kurikulum. Hal ini menunjukkan bahwa ada ketidakcocokan antara evaluasi pembelajaran dengan tujuan pendidikan di era pembelajaran mandiri.
\end{abstract}

Keywords : Problematika, Evaluasi Pembelajaran, Pandemi Covid 19

\section{PENDAHULUAN}

Pendidikan masa kini dihadapkan pada keadaan yang berat yaitu pandemic covid 19, keadaan ini memacu peserta didik supaya mampu mengimbangi berbagai dinamika perubahan kehidupan yang kompleks. Perubahan yang terjadi berkaitan dengan perkembangan ilmu pengetahuan dan teknologi, social dan budaya serta perubahan dalam nilai moral dan sikap yang dimana akan membuat pergeseran dalam kehidupan bermasyarakat, hal ini tentu berpengaruh terhadap tujuan pendidikan yang telah dirumuskan berdasarkan fungsi dan tujuan pendidikan nasional yang tertuang dalam Undang-Undang Nomor 20 Tahun 2003 Pasal 3 yang berbunyi pendidikan nasional berfungsi mengembangkan kemampuan watak serta peradaban bangsa yang bermartabat dalam rangka mencerdaskan kehidupan bangsa serta mengembangkan potensi peserta didik agar menjadi manusia yang beriman dan bertaqwa kepada Tuhan Yang Maha Esa, berakhlaq mulia, sehat,berilmu, cakap, kreatif, mandiri dan menjadi warga negara yang demokratis serta bertanggung jawab.

Untuk mencapai tujuan tersebut dalam masa pandemi ini merupakan hambatan sekaligus tantangan bagi semua Stakeholder yang berkontribusi dalam dunia Pendidikan. Konsep belajar dan evaluasi pembejaran yang sesuai dengan masa saat ini adalah pembelajaran dalam jaringan (Daring)

Pembelajaran daring (online) pertama kali dikenal karena pengaruh dari perkembangan pembelajaran berbasis elektronik (e-learning) yang diperkenalkan oleh Universitas Illionis melalui sistem pembelajaran berbasis komputer (Hardiayanto). Online learning merupakan suatu sistem yang dapat memfasilitasi siswa belajar lebih luas, lebih banyak, dan bervariasi. Melalui fasilitas yang disediakan oleh sistem tersebut, siswa dapat belajar kapan dan dimana saja tanpa terbatas oleh jarak, ruang dan waktu. Materi 
pembelajaran yang dipelajari lebih bervariasi, tidak hanya dalam bentuk verbal, melainkan lebih bervariasi seperti visual, audio, dan gerak.

Evaluasi pembelajaran adalah hal mutlak diperlukan untuk mengetahui sejauh mana tingkat capaian kemampuan yang dimiliki peserta didik, ini diperlukan karena dapat dijadikan acuan dalam merumuskan dan menetapkan suatu kebijkan pembelajaran selanjutnya. Evaluasi memiliki makna yang berbeda dengan penilaian dan pengukuran. Evaluasi didahului dengan penilaian (assessment), sedangkan penilaian didahului dengan pengukuran. Pengukuran dapat diartikan sebagai kegiatan membandingkan hasil pengamatan atau informasi karakteristik suatu objek. Oleh karena itu, penilaian menjadi proses terpenting dalam menentukan hasil evaluasi pembelajaran.

Penilaian (assessment) merupakan komponen penting dalam kegiatan pembelajaran. Menurut Mardapi dalam Widoyoko (2011) kualitas pembelajaran dapat dilihat dari hasil penilaiannya. Sistem penilaian yang baik akan mendorong guru untuk menentukan strategi mengajar yang baik dan memotivasi siswa untuk belajar yang lebih baik. Dengan demikian, secara tidak langsung guru juga sudah sepatutnya untuk berupaya meningkatkan kualitasnya sebagai guru.

Riadi (2017) menyatakan bahwa guru merupakan sumber daya utama dari pembelajaran, sehingga evaluasi terhadap guru termasuk bagian penting dari kegiatan evaluasi pembelajaran di sekolah. Hal ini karena guru diyakini memiliki peran penting dalam meningkatkan keseluruhan kualitas pendidikan. Pada pelaksanaan evaluasi pembelajaran setiap guru seharusnya paham dengan tujuan dan manfaat dari evaluasi atau penilaian. Tak jarang terdapat pula guru yang tidak memperdulikan hal ini, yang terpenting ia masuk kelas, mengajar, monoton dalam dalam pelaksanaan evaluasi, berorientasi pada nilai akhir, kebebasan guru dalam waktu pelaksanaan evaluasi yang sesuai atas kemauan dan kemudahan guru tanpa memperdulikan konsep dasar evaluasi untuk tujuan pendidikan, terlebih di masa pandemic seperti sekarang ini.

Adanya evaluasi dimasa pandemi covid 19, seharusnya menjadikan guru berperan lebih aktif sebagai perantara untuk mewujudkan tujuan pendidikan. Guru mampu memahami tujuan dan fungsi evaluasi pembelajaran yang semestinya. Selain itu, guru mampu mewujudkan pembelajaran yang nyaman, menyenangkan, dan menarik walaupun dalam masa pandemic covid 19.

\section{METODE PENELITIAN}

Penelitian ini berusaha mengetahui, memahami dan mendeskripsikan permasalahan pada pelaksanaan evaluasi pembelajaran dalam mencapai tujuan pendidikan di masa pandemic covid 19. Dalam hal ini, peneliti melakukan penelitian dengan cara penelitian deskriptif dengan menggunakan pendekatan kualitatif. Menurut Bogdan dan Taylor (1992:2122), penelitian kualitatif adalah salah satu prosedur penelitian yang menghasilkan data deskriptif berupa ucapan atau tulisan dan perilaku orang-orang yang diamati. Adapun teknik pengumpulan data yang digunakan pada penelitian ini disesuaikan dengan tujuan dari penelitian ini yaitu studi pustaka (studi literatur). Studi kepustakaan berkaitan dengan kajian teoritis dan referensi lain yang berkaitan dengan nilai, budaya dan norma yang berkembang pada situasi sosial yang diteliti, selain itu studi kepustakaan sangat penting dalam melakukan penelitian, hal ini dikarenakan penelitian tidak akan lepas dari literatur-literatur Ilmiah (Sugiyono, 2017: 291).

Sumber riset pustaka pada penelitian ini diambil dari buku cetak, jurnal ilmiah, dan artikel berita online yang memuat informasi mengenai permasalahan yang akan dibahas pada penelitian ini, yaitu problematika evaluasi pembelajaran dalam mencapai tujuan pendidikan di masa pandemic covid-19. 


\section{HASIL DAN PEMBAHASAN}

\section{Evaluasi Pembelajaran}

Kata evaluasi sering digunakan dalam pendidikan. Dalam konteks ini, evaluasi berarti penilaian atau pengukuran. Namun, banyak dari kita yang belum memahami secara tepat arti kata evaluasi, pengukuran, dan penilaian. Bahkan, banyak orang mengartikan ketiganya dengan satu pengertian yang sama. Hal ini karena orang hanya mengidentikkan kegiatan evaluasi sama dengan menilai. Karena biasanya, aktivitas mengukur sudah termasuk di dalamnya. Pengukuran, penilaian, dan evaluasi merupakan kegiatan yang tidak dapat dipisahkan satu sama lain, dan dalam pelaksanaannya harus dilakukan secara berurutan.

Kegiatan evaluasi hasil belajar memerlukan data yang diperoleh dari kegiatan pengukuran. Kegiatan pengukuran memerlukan instrument yang diharapkan menghasilkan data yang shahih dan andal. Kegiatan pengukuran dalam proses pembelajaran dapat dilakukan dalam bentuk tugas- tugas rumah, kuis, ulangan tengah semester, dan akhir semester.

Selanjutnya, tentang istilah evaluasi. Secara harfiah, evaluasi berasal dari Bahasa Inggris, yaitu "evaluation". Sedangkan dalam Bahasa Arab yakni "at- taqdir" yang berarti penilaian atau penaksiran. Menurut Cross, evaluasi meruapakan proses yang menentukan kondisi, dimana suatu tujuan telah dapat dicapai. Definisi ini menerangkan secara langsung hubungan evaluasi dengan tujuan suatu kegiatan mengukur derajat, di mana suatu tujuan dapat dicapai. Sebenarnya, evaluasi juga merupakan proses memahami, memberi arti, mendapatkan, dan mengkomunikasikan suatu informasi bagi keperluan mengambil keputusan. Zainul dan Nasution menyatakan bahwa evaluasi dapat dinyatakan sebagai proses pengambilan keputusan menggunakan informasi yang diperoleh melalui pengukuran hasil belajar, baik menggunakan instrument tes maupun non- tes. Arikunto mengungkapkan bahwa evaluasi adalah serangkaian kegiatan yang ditujukan untuk mengukur keberhasilan program pendidikan. Dengan demikian, evaluasi dapat didefinisikan sebagai suatu proses sistematis untuk menentukan atau membuat keputusansampai mana tujuan- tujuan pembelajaran dicapai siswa.

Berdasarkan pengertian tersebut, ada beberapa hal yang perlu dipahami lebih lanjut bahwa Evaluasi adalah suatu proses, bukan suatu hasil (produk). Hasil yang diperoleh dari kegiatan evaluasi adalah kualitas sesuatu. Baik yang menyangkut nilai atau arti, sedangkan kegiatan untuk sampai pada pemberian nilai dan arti itu adalah evaluasi. Memebahas evaluasi berarti mempelajari bagaimana proses pemberian pertimbangan mengenai kualitas sesuatu.

Evaluasi merupakan salah satu rangkaian kegiatan dalam meningkatkan kualitas, kinerja, atau produktivitas suatu lembaga dalam melaksanakan programnya. Melalui evaluasi akan diperoleh tentang apa yang telah dicapai dan mana yang belum, dan selanjutnya informasi ini digunakan untuk perbaikan suatu program.

Evaluasi selalu mengandung proses. Proses evaluasi harus tepat terhadap tipe tujuan yang biasanya dinyatakan dalam bahasa perilaku. Dikarenakan tidak semua perilaku dapat dinyatakan dengan alat evaluasi yang sama, maka evaluasi menjadu salah satu hal yang sulit dan menantang, yang harus disadari oleh guru. Menurut Undang- Undang Republik Indonesia No. 20 Tahun 2003 tentang Sistem Pendidikan Nasional Pasal 57 ayat (1), evaluasi dilakukan dalam rangka pengendalian mutu pendidikan secara nasional sebagai bentuk akuntabilitas penyelenggaraan pendidikan kepada pihak- pihak yang berkepentingan di antaranya terhadap siswa, lembaga, dan program pendidikan.

Secara umum, tujuan evaluasi dalam bidang pendidikan ada dua. Pertama, untuk menghimpun berbagai keterangan yang akan dijadikan sebagai bukti perkembangan yang dialami oleh para siswa setelah mereka mengikuti proses pembelajaran dalam jangka waktu tertentu. Dengan kata lain, tujuan umum evaluasi dalam pendidikan yakni memperoleh data pembuktian yang akan menjadi petunjuk tingkat kemampuan dan keberhasilan siswa dalam pencapaian berbagai tujuan kurikuler setelah menempuh proses pembelajaran dalam jangka waktu yang telah ditentukan. 


\section{Tujuan Pendidikan}

Pendidikan bertujuan untuk mengubah karakter manusia sebagai makhluk Tuhan dan warga negara yang berkepribadian baik, guna meningkatkan pengalaman dan kualitas diri. Menurut Musanna (2017) tujuan pendidikan tercermin pada pengertian pendidikan yang dikemukakan Ki Hajar Dewantara. Ki Hajar Dewantara memaknai pendidikan sebagai proses pemberian tuntunan untuk menumbuhkembangkan potensi anak. Ini sejalan dengan tujuan Pendidikan dalam UU Sistem Pendidikan Nasional Pasal 3 yang berbunyi Pendidikan nasional berfungsi mengembangkan kemampuan dan membentuk watak serta peradaban bangsa yang bermartabat dalam rangka mencerdaskan kehidupan bangsa, bertujuan untuk berkembangnya potensi peserta didik agar menjadi manusia yang beriman dan bertakwa kepada Tuhan Yang Maha Esa, berakhlak mulia, sehat, berilmu, cakap, kreatif, mandiri, dan menjadi warga negara yang demokratis serta bertanggung jawab.

\section{Masa Pandemi Covid 19}

Corona Virus pertama kali munccul di kota Wuhan di Provinsi Hubei Cina pada bulan Desember tahun 2019 lalu. Virus ini merupakan penyakit yang disebabkan oleh infeksi virus SARS-CoV-2. Di Indonesia sendiri sudah menyebar diberbagai daerah, bahkan sudah menyebar diseluruh penjuru dunia. Jumlah kasus positif virus corona di Indonesia terus bertambah dengan minimnya kesadaran masyarakat didalamnya. Corona Virus sebelumnya dikenal sebagai Novel 201 Novel Coronavirus (2019-nCoV) penyakit pernapasan. Nama ini disebutkan sebelum Organisasi Kesehatan Dunia (WHO) menyatakan nama resmi sebagai Covid-19 pada bulan Februari 2020.

Corona Virus adalah sekumpulan virus yang bisa menjalar dari hidung, mata dan bagiannya lainnya dan mampu menginfeksi sistem pernapasan dan beberapa organ tubuh lainnya. Pada kebanyakan kasus, virus ini sebenernya hanya menimbulkan infeksi pernapasan ringan, seperti flu. Namun, virus ini juga dapat menyebabkan infeksi pada pernapasan berat, seperti infeksi paru-paru (pneumonia).

Gejala awal yang ditimbulkan oleh infeksi virus Corona atau Covid-19 dapat dirasakan seperti gejala flu, yaitu demam, pilek, batuk kering, sakit tenggorokan, dan sakit kepala. Setelah itu, gejala tersebut bisa hilang ataupun semakin menular dan bisa menjadi lebih berat dari sebelumnya. Penderita dengan gejala yang berat dapat merasakan demam tinggi, batuk berdahak bahkan berdarah, sesak napas, dan nyeri dada. Gejala-gejala tersebut muncul ketika tubuh tidak mampu melawan virus Corona.

Pandemi Covid-19 menjadi permasalahan multidimensi yang dihadapi dunia. Dunia seakan berubah dengan adanya penyebaran virus ini. Perubahan terjadi pada bidang ekonomi, teknologi, politik hingga pada bidang pendidikan yang tentunya membuat penuruan dalam kualitas belajar pada peserta didik (Sahu, 2020), akaibat pandemi ini mengharuskan dan membuat sistem pembelajaran berganti menjadi pembelajaran daring agar proses pembelajaran tetap berlangsung sehingga peserta didik mendapatkan hak belajarnya (Sintema, 2020), hal tersebut sangat jelas mengubah dan mengganti pola pembelajaran dan pendekatan yang mengharuskan guru dan pengembang pendidikan untuk menyiapkan dan menyediakan bahan pembelajaran dan guru harus mengajarkan materi kepada peserta didik secara langsung melalui online dengan alat digital jarak jauh (United Nations, 2020).

\section{Pembelajaran Daring}

Pembelajaran daring adalah unsur teknologi informasi dalam pembelajaran yang berguna dalam membuat inovasi dalam pendidikan. Menurut Mustofa et al (2019) bahwa Pembelajaran daring merupakan aktivitas pengajaran yang dilaksanakan secara terpisah dari aktivitas belajar dan dilakukan dengan jarak jauh. Pembelajaran daring dilakukan dengan peralatan teknologi seperti jaringan internet dan aplikasi yang sesuai dengan kebutuhan (Alessandro, 2018), artinya bahwa jaringan internet digunakan sebagai sistem dalam pembelajaran daring. Crews \& Parker, Mather \& Sarkans, (2018), mengatakan bahwa 
kebanyakan dalam perguruan tinggi seperi penelitian yang pernah dilakukan, pembelajaran daring menjadi salah satu solusi dalam melaksanakan pembelajaran. Riaz, (2018), juga mengatakan bahwa setiap orang sangat terbantu dalam mengakses belajar dengan pembelajaran daring dan hal tersebut sangat efektif digunakan di perguruan tinggi, namun menurut Pilkington (2018) tidak semua pembelajaran dilakukan dengan pembelajaran daring.

Menurut Ghirardini (2011) pembelajaran daring merupakan pembelajaran yang memberikan sebuah cara yang efektif dan kreatif dalam belajar. Pembelajaran daring dalam hal ini memberikan adanya timbal balik yang cepat, memberikan pembelajaran yang berinovasi dengan adanya teknologi yang digunakan. Pada kesempatan yang sama, peserta didik mendapatkan ilmu pengetahuan yang sama dengan adanya guru yang tidak membebani peserta didik dalam kegiatan pembelajaran.

Menurut Ghirardini (2011) menjelaskan bahwa daring content, interaktif e-lesson, simulasi elektronik, job aids, dapat digabungkan melalui sebuah pendekatan dengan daring. Sumber daya non-interaktif seperti dokumen, PowerPoint presentasi, video atau file audio disebut Daring content (sumber sederhana belajar). Ketika mahasiswa membaca atau menonton konten tanpa melakukan tindakan lain dimaksudkan dengan bahan-bahan ini noninteraktif. Hal ini sangat mudah dan cepat ketika dikembangkan, karena ketika semuanya sudah lengkap dengan tujuan dan bahan yang dirancang dengan bagus, hal ini menjadi sangat penting walaupun tidak memberikan timbal balik sekalipun.

Interaktif e-lesson yakni pelatihan berbasis web yang terdiri dari satu set interactive e lessons yang dilakukan dengan pendekatan yang paling umum. Sebuah e-lessons adalah interaktivitas dalam bentuk pertanyaan dan umpan balik yang mencakup teks, grafik, animasi, audio, video dan semua itu saling mencakup didalamnya serta mencakup informasi tambahan tentang topik tertentu, rekomendasi membaca dan link ke sumber daya online.

Simulasi elektronik adalah pola yang dilakukan interaktif daring. Istilah simulasi merupakan suatu bentuk yang dilakukan dalam menciptakan suasana belajar dalam dunia nyata yang sangat membantu peserta didik dalam melakukan interaksi dalam proses. Simulasi adalah sebuah aksi yang dilakukan dalam bentuk pelatihan secara konkrit melihat keadaan dengan langsung sebelum memulai pada aktivitas yang sebenarnya.

Job aids menjelaskan tentang pengetahuan pada masa sekarang. Semua dapat menggunakan bentuk yang berbeda sesuai pada keinginan masing-masing. Mereka akan memberikan timbal balik dalam bentuk jawaban yang jelas dan spesifik, sehingga memudahkan pengguna dapat mengerjakan dan menyelesaikan tugas dengan baik.

Siahaan, (2003) mengatakan bahwa daring mempunyai tiga fungsi dalam aktivitas pembelajaran di dalam kelas yakni: suplemen, komplemen, dan substitusi. Maksud sebagai suplemen (tambahan) adalah peserta didik mempunyai kebebasan dalam memilih, mereka akan memanfaatkan materi dan tugas dalam daring atau tidak. Jika peserta didik mampu memanfaatkan materi tersebut, maka mereka akan mendapatkan ilmu pengetahuan yang lebih, sebaliknya jika tidak maka mereka tidak mendapatkan apapun sama sekali.

Dikatakan berfungsi sebagai komplemen (pelengkap) adalah materi yang disampaikan merupakan materi sebagai pelengkap dari materi yang sebenernya diberikan oleh guru. Maksudnya adalah materi daring tersebut merupakan pengayaan bagi peserta didik yang masih kurang dalam mengikuti pembelajaran daring sebelumnya.

Dari beberapa contoh tersebut sebenernya sudah bisa memberikan model pembelajaran yang mudah dan bisa diikuti oleh peserta didik, namun kembali ke peserta didik yang bersangkutan karena pembelajaran daring ini tidak bisa langsung dikontrol oleh guru, maka dari itu kembali ke peserta didik, apakah materi yang diberikan mampu dimanfaatkan dengan baik atau tidak. Jika mampu dimanfaatkan maka tujuan dari pembelajaran daring yang diinginkan mampu tercapai dengan baik. 


\section{Problematika Evaluasi Pembelajaran di Masa Pandemi covid 19 dalam Mencapai Tujuan Pendidikan}

Pandemi Covid-19 berdampak besar pada berbagai sektor, salah satunya pendidikan. Dunia pendidikan juga ikut merasakan dampaknya. Pendidik harus memastikan kegiatan belajar mengajar tetap berjalan, meskipun peserta didik berada di rumah. Solusinya, pendidik dituntut mendesain media pembelajaran sebagai inovasi dengan memanfaatkan media daring (online). Ini sesuai dengan Menteri Pendidikan dan Kebudayaan Republik Indonesia terkait Surat Edaran Nomor 4 Tahun 2020 tentang Pelaksanaan Kebijakan Pendidikan dalam Masa Darurat Penyebaran Corona Virus Disease (Covid-19).

Sistem pembelajaran dilaksanakan melalui perangkat personal computer (PC) atau laptop yang terhubung dengan koneksi jaringan internet. Pendidik dapat melakukan pembelajaran bersama di waktu yang sama menggunakan grup di media sosial seperti WhatsApp (WA), telegram, instagram, aplikasi zoom ataupun media lainnya sebagai media pembelajaran.

Dengan demikian, pendidik dapat memastikan peserta didik mengikuti pembelajaran dalam waktu bersamaan, meskipun di tempat yang berbeda. Pendidik pun dapat memberi tugas terukur sesuai dengan tujuan materi yang disampaikan kepada peserta didik. Kondisi pandemi Covid-19 ini mengakibatkan perubahan yang luar biasa, termasuk bidang pendidikan. Seolah seluruh jenjang pendidikan 'dipaksa' bertransformasi untuk beradaptasi secara tiba-tiba drastis untuk melakukan pembelajaran dari rumah melalui media daring (online). Ini tentu bukanlah hal yang mudah, karena belum sepenuhnya siap. Problematika dunia pendidikan yaitu belum seragamnya proses pembelajaran, baik standar maupun kualitas capaian pembelajaran yang diinginkan.

Berbagai aplikasi media pembelajaran pun sudah tersedia, baik pemerintah maupun swasta. Pemerintah mengeluarkan Surat Edaran Menteri Pendidikan dan Kebudayaan Nomor 9/2018 tentang Pemanfaatan Rumah Belajar. Pihak swasta pun menyuguhkan bimbingan belajar online seperti ruang guru, Zenius, Klassku, Kahoot, dan lainnya. Akses-akses tersebut dapat dimanfaatkan untuk mengembangkan pengetahuan danwawasan. Sangat diperlukan peningkatan kualitas sumber daya manusia (SDM). Keberhasilan pembangunan negara salah satu tolak ukurnya adalah keberhasilan pendidikan. Melalui pendidikan, akan melahirkan generasi penerus yang cerdas intelektual maupun emosional, terampil, dan mandiri untuk mencapai pembangunan bangsa ini. Namun muncul polemik masyarakat pada metamorfosa di masa pandemi Covid-19.

Hal ini tentu dirasa berat oleh pendidik dan peserta didik. Terutama bagi pendidik, dituntut kreatif dalam penyampaian materi melalui media pembelajaran daring. Ini perlu disesuaikan juga dengan jenjang pendidikan dalam kebutuhannya. Dampaknya akan menimbulkan tekanan fisikmaupun psikis (mental). Pola pikir yang positif dapat membantu menerapkan media pembelajaran daring, sehingga menghasilkan capaian pembelajaran yang tetap berkualitas. Belajar di rumah dengan menggunakan media daring mengharapkan orangtua sebagai role model dalam pendampingan belajar anak, dihadapi perubahan sikap.

Masa pandemi Covid-19 ini bisa dikatakan sebagai sebuah peluang dalam dunia pendidikan, baik pemanfaatan teknologi seiring dengan industri 4.0, maupun orangtua sebagai mentor. Harapannya, pasca-pandemi Covid-19, kita menjadi terbiasa dengan sistem saat ini sebagai budaya pembelajaran dalam pendidikan. Wabah Covid-19 ditetapkan sebagai pandemi global dan BNPB menetapkan status darurat nasional. Berkaitan dengan hal tersebut pemerintah telah melakukan upaya preventif guna mencegah dan meminimalkan penyebaran virus tersebut. Kebijakan yang diambil pemerintah Indonesia yaitu dengan menerapkan social distancing atau menjaga jarak dan Work From Home (WFH) baik pegawai negeri maupun swasta sejak Maret lalu. Kebijakan ini mempunyai beberapa implikasi pada berbagai bidang, tidak terkecuali bidang pendidikan.

Menteri Pendidikan dan Kebudayaan RI Nadiem Anwar Makarim merespon dengan kebijakan belajar dari rumah melalui pembelajaran daring. Padahal, interaksi guru dan siswa 
dalam proses pembelajaran sangat penting untuk mengetahui kemajuan proses belajar siswa. Hal ini menjadi tantangan bagi guru agar berinovasi dalam proses pembelajaran secara daring, tak terkecuali guru BK. Guru BK dituntut untuk tetap melakukan konseling walaupun tidak dengan face to face seperti yang biasanya dilakukan.

\section{PENUTUP}

\section{Simpulan}

Pada masa pandemi covid 19 pembelajaran daring merupakan hal mutlak yang harus dilakukan baik itu proses kegiatan belajar mengajarnya dan juga evaluasi pembelajarannya. Semua ini dilakukan untuk mencapai tujuan, metode, materi, dan evaluasi pembelajaran yang efektif efisien dan bermutu. Kegiatan evaluasi inilah yang menjadikan guru berperan sebagai perantara untuk mewujudkan tujuan pendidikan di masa pandemi. Guru harus memahami tujuan dan fungsi evaluasi pembelajaran pada masa pandemic sehingga mampu menyiapkan metode strategi yang handal dalam pembelajaran daring ini sehingga mampu mewujudkan pembelajaran yang nyaman, menyenangkan, dan menarik, sehingga kegiatan evaluasi pun berfungsi sebagaimana mestinya. Realitanya, terdapat guru yang tidak memperdulikan hal tersebut. Pada pembelajaran yang terpenting guru masuk kelas, mengajar, melakukan evaluasi yang monoton, mengutamakan pada nilai akhir, melaksanakan waktu evaluasi sesuai atas kemauan dan kemudahan guru tanpa memperdulikan konsep dasar evaluasi untuk tujuan pendidikan. Anggapan guru yang terpenting pada akhir semester ia telah mencapai target kurikulum. Hal tersebut menunjukkan adanya keti- daksesuaian antara evaluasi pembelajaran dengan tujuan pendidikan di era merdeka belajar.

\section{DAFTAR PUSTAKA}

Alessandro, B. (2018). Digital Skills and Competence, and Digital and Online Learning. Turin: European Training Foundation

Bogdan, Robert dan Taylor, Pengantar Metode Penelitian Kualitatif, Terjemahan oleh Arief Rurchan, (Surabaya : Usaha Nasional, 1992).

Ghirardini, B. (2011). E-learning Methodologies. Germany: Federal Ministry of Food, Agriculture and Consumer Protection

Melfianora. (2019). Penulisan Karya Tulis Ilmiah dengan Studi Literatur. Diakses dari http://osf.io/efmc2/

Mustofa, M. I., Chodzirin, M., Sayekti, L., \& Fauzan, R. (2019). Formulasi Model Perkuliahan Daring sebagai Upaya Menekan Disparitas Kualitas Perguruan Tinggi. Walisongo Journal of Information Technology, 1(2), 151. https://doi.org/10.21580/wjit.2019.1.2.4067.

Musanna, A. (2017). Indigenisasi Pendidikan: Rasio- nalitas Revitalisai Praksis Pendidikan Ki Hajar Dewantara. Jurnal Pendidikan dan Kebudayaan, 2(1), 122-123. Diak- ses dari https://www.google.com/url?sa=t\&source=we $\mathrm{b} \& \mathrm{rct}=\mathrm{j} \&$ url=https://media.neliti.com/media/publication_s/178718-none1445784f.pdf\&ved=2ahUKEwi2r4LahNDnAhWqzjgGHQ9oCoYQFjAAegQIBh AC\&usg=AOvVaw3Vvw--4KLGEgj80TYL1qPd

Pilkington, O. A. (2018). Active Learning for an Online Composition Classroom: Blogging as an Enhancement of Online Curriculum. Journal of Educational Technology Systems, 47(2), 1-14. https://doi.org/10.1177/0047239518788278.

Riadi, A. (2017). Problematika Sistem Evaluasi Pem- belajaran. Ittihad Jurnal Kopertais Wilayah XI Kalimantan,15(27), 2-9. Diakses dari https://www.google.com/url?s $\mathrm{a}=\mathrm{t} \&$ source=web\&rct=j\&url=https://jurnal.uin-antasari. ac.id/index.php/ittihad/article/download/1593/1162\&ved $=2$ ahUKEwjwzoj5hNDn AhUFwjgGHZqqDmkQFjAB $\quad$ egQICRAB\&usg=AOvVaw0nW1LBs3bhgW $\underline{\mathrm{kGgJzz} 0-}$ 
Sahu, P. (2020). Closure of Universities Due to Coronavirus Disease 2019 (COVID-19): Impact on Education and Mental Health of Students and Academic Staff. Cureus, 2019 (April). https://doi.org/10.7759/cureus.7541.

Sintema, E. J. (2020). Effect of COVID-19 on the Performance of Grade 12 Students: Implications for STEM Education. Eurasia Journal of Mathematics, Science and Technology Education, 16(7), 1-6. https://doi.org/10.29333/ejmste/7893.

Sugiyono. 2018. Metode Penelitian Kuantitatif, Kualitatif, dan R\&D. Bandung: Alfabeta. Undang-Undang Republik Indonesia Tahun 2003 tentang Sistem Pendidikan Nasional. Widoyoko, E.P. (2011). Evaluasi Program Pembelajaran. Yogyakarta: Pustaka belajar. Djemari Mardapi, Pengukuran, Penilaian, dan Evaluasi Pendidikan. 